\title{
AS ORGANIZAÇÕES SOCIAIS E A REFORMA ADMINISTRATIVA
}

\author{
ATALIBA PINHEIRO ESPÍRITO SANTO*
}

\begin{abstract}
1. Introdução - 2. Da contextualização das organizações sociais - 3. Das observaçōes acerca da Lei $n^{\circ} 9.637 / 98$ - 4. Da natureza dos serviços não-exclusivos - 5. Conclusão - 6. Bibliografia
\end{abstract}

\section{Introdução}

Na Exposição de Motivos Interministerial $n^{\circ} 49$, de 18.08.1995, apresentada ao Presidente da República, justificando a proposta de emenda constitucional acerca da reforma administratival, o conselho de ministros que a produziu ressalvou naquele texto três dimensões da "crise do Estado", dentre as quais a "crise do próprio aparelho estatal" que a sobredita proposta de emenda visava debelar. Apesar da consciência de que o tema não se esgotava com aquela "revisão de dispositivos constitucionais", a mesma tinha por expectativa "transformar a administração pública em poderoso instrumento de desenvolvimento econômico e social".

Aprovado no mês de novembro do mesmo ano pelo Presidente da República, o Plano Diretor da Reforma do Estado ${ }^{2}$, registro tático das sobreditas expectativas, formulado a partir da presunção de que seria aquele o momento propício para "dar um salto adiante, no sentido de uma administração pública... 'gerencial', baseada em conceitos atuais de administração e eficiência", revela que seus idealizadores entendiain ser possivel identificar quatro setores de atuação do Estado: o núcleo estratégico, as atividades exclusivas, os servicos não-exclusivos e a produção de bens e serviços para o mercado.

* Advogado no Rio de Janeiro. e-mail: ataliba@openlink.com.br

1 PEREIRA JR., Jessé Tortes. Da reforma administrativa constitucional. Rio de Janeiro: Renovar, 1999, pp. 1-3.

2 BRASL. Ministério do Planejamento, Orçamento e Gestão. Plano Diretor da Reforma do Estado. Disponível em: "http://www.planejamento.gov.br/gestao/conteudo/publicacoes/plano_diretor/portugues_tudo.htm". Acesso em: 01.08.2002.

3 BRASIL. Op. cit., Apresentação. 
No supramencionado documento, seus redatores declararam ser "possivel imaginar avanços na direção da modernização da gestão pública, a partir de ações específicas de laboratórios visando ao estabelecimento de duas instituições básicas: as 'agências autônomas' entre as atividades exclusivas de Estado, e as 'organizações sociais' entre os serviços competitivos ou não-exclusivos". " Outrossim, relativamente a estes últimos, registraram a crença de que com tal desenho a Reforma do Estado iria "tomar também muito mais eficientes os serviços sociais competitivos ao transformá-los em organizações públicas não-estatais de um tipo especial " (sic) ${ }^{5}$

Com efeito, supostamente ainda em curso, a Reforma acaba por relacionar-se de um lado com a dinâmica interna na própria administração pública na medida em que busca consolidar uma "cultura gerencial", de outro com a expectativa "do surgimento de uma nova sociedade, baseada na participação popular, que recoloca o Estado como instrumento do exercício pleno da cidadania" 6

O texto do Plano Diretor deixa antever que, para além dos chamados projetos adicionais $^{7}$, os projetos relativos às agências autônomas ${ }^{8}$, gênero do qual uma das duas instituições básicas do Estado a ser reformado é espécie - as agências executivas —, formavam com a outra instituição básica - as organizações sociais — os pilares de sustentação da Reforma, sendo certo que, para a consecução destas últimas, se fazia necessáiro elaborar e aprovar lei que permitisse a "Publicização" dos "serviços não-exclusivos do Estado, ou seja, sua transferência do setor estatal para o público não-estatal", consoante o pressuposto que atribuía maior eficiência às organizações sociais para a realização daqueles serviços.

Tanto antes quanto posteriormente à Exposição de Motivos Interministerial $\mathbf{n}^{\circ}$ 49, da lavra do principal promotor das mudanças propostas, LUIZ CARLOS BRESSER PEREIRA, então à frente do extinto Ministério da Administração Federal e Reforma do Estado, a sobredita concepção das organizações sociais foi divulgada em variados trabalhos ${ }^{9}$, os quais objetivavam esclarecê-la plenamente. Aquele ideá-

4 BRASIL. Op. cit, 7.5 A Dinâmica da Transição.

5 BRASIL. Ministério do Planejamento, Orçamento e Gestão. Plano Diretor da Reforma do Estado. Disponivel em: http:/www.planejamento.gov.br/gestao/conteudo/publicacoes/plano_diretor/portugues_tudo.htm. Acesso em: 01.08.2002. 6. Objetivos.

6 BRASIL. Op. cit., 7.5 A Dinâmica da Transição.

7 BRASIL. O. cit.: 8.2.1 Projeto Cidadão; 8.2.2. Indicadores de Desempenho; 8.2.3 Qualidade e Participação; 8.2.4 Nova Política de Recursos Humanos; 8.2.5 Valorização do Servidor para Cidadania: 8.2.6 Desenvolvimento de Recursos Humanos; 8.2.7 Revisão da Legislação Infra-Constitucional; 8.2.8 Rede do Governo; 8.2.9 Sistema de Gestão Pública.

8 BRASIL. Op. cit., 8.1.2. Agências Autônomas.

9 PEREIRA, Luiz Carlos Bresser. A reforma do aparelho do Estado e a Constituição Brasileira. Brasília: ENAP, 1995. (Texto para discussão, $n^{\circ} 1$ ); Idem. A Reforma do estado dos antos 90: lógica e mecanismos de controle. Lua Nova, São Paulo, n 45, p. 49-95, 1998; Idem. Da administração Pública burocrática à gerencial. in: PEREIRA, Luiz Carlos Bresser; SPINK, Peter Kevin. (Org.) Reforma do Estado e administração pública gerencial. Rio de Janeiro: Editora FGV, 2001, p. 238-70; Idem. Exposição no Senado sobre a Reforma da Administração Pública. Brasília: MARE, 1997. (Cadernos MARE da reforma do estado; $n^{\circ} 3$ ); Idem. Gestão do setor público: estratégia e estrutura para um novo Estado. in: PEREIRA, Luiz Carlos Bresser; SPINK, Peter Kevin. (Org.) 
rio parecer ter sido aceito por boa parcela dos cientistas sociais e, ainda que de forma não hegemônica, por diversos administrativistas ${ }^{10}$, como o caminho a ser trilhado pela sociedade brasileira para a solução dos graves problemas que sempre colocaram o país, no plano internacional, em posição de não causar inveja a ninguém no Ocidente $^{11}$.

O presente trabalho tem por objetivo rever alguns aspectos relativos às organizações sociais e sua ligação com a Reforma Administrativa, na medida em que, s.m.j., certas questões parecem não ter sido totalmente exploradas.

Partindo das diretrizes e esclarecimentos consignados no Plano Diretor da Reforma do Estado, através do registro de algumas observações e críticas acerca da lei das organizações sociais - Lei $n^{\circ} 9.637 / 98$, da averiguação da natureza dos serviços não-exclusivos e do critério de fixação dos mesmos, se busca entender até que ponto a Reforma Administrativa no geral, e a instituição das organizações sociais, em particular, serão capazes de contribuir para que o Estado lidere a tarefa de tornar a sociedade brasileira mais democrática e justa.

\section{Da contextualização das organizações sociais}

Relativamente ao Brasil, de forma mais destacada após a promulgação da Constituição Federal de 1988, torna-se visível o quadro político no qual o Estado

Reforma do Estado e administraçāo pública gerencial. Rio de Janeiro: Editora FGV, 2001. p. 21-38; Idem. Reforma do Estado para a Cidadania. São Paulo: Editora 34, 1998, p. 235-50; Idem. Uma reforma gerencial da Administração Pública no Brasil. Revista do Serviço Público, Brasília: ENAP, Ano $49, \mathrm{n}^{\circ} 1$, p. 5-42, 1998.

10 Sob o título "JURISTAS AJUDARÃO A REGULAMENTAR A REFORMA ADMINISTRATIVA", em 17.04.1998, o Ministério do Planejamento, Orçamento e Gestão divulgou informaçāo na qual declara que ao "convidar juristas de renome, o MARE abre a regulamentação da Reforma Administrativa à participação da sociedade civil e pretende assegurar a elevada qualidade técnico-jurídico às propostas a serem enviadas ao Congresso Nacional". Disponível em: http:/www.planejamento.gov.br/gestao/conteudo/publicacoes/reforma_estado/mudanca/juristas.htm. Acesso e m: 01.08.2002.

11 Segundo o Relatório de Desenvolvimento Humano 2002, publicado para o Programa das Nações Unidas para o Desenvolvimento (PNUD), o Brasil ocupa a $73^{\mathrm{a}}$ posição entre os 75 países detentores dos maiores Índices de Desenvolvimento Humano (IDH). Todavia, como somente para 48 deles está disponível a informaçāo acerca do Índice de Gini (mede a Desigualdade no Rendimento ou no Consumo), resulta da nova análise a seguinte posição brasileira: pior IDH ( $48^{\circ}$ lugar), segunda pior expectativa de vida ( $47^{\circ}$ lugar), pior percentual de alfabetização de adultos ( $48^{\circ}$ lugar), segunda maior população (inferior apenas à população dos Estados Unidos) e, apesar de não ser o Estado mais pobre ( $38^{\mathrm{a}}$ posição em renda per capita), possui a sociedade mais desigual ( $48^{\circ} \mathrm{lugar}$ ). Convém observar que, entre 1980 e 2000 , o Brasil obteve o sétimo maior crescimento percentual de IDH $(11,5 \%)$, contudo, consoante análise de informaçôes divulgadas pelo IPEA, no período 1979-99, praticamente o mesmo, a desigualdade não arrefeceu, saindo de 0,605 para 0,596 , o que significa melhoria de apenas $1.5 \% \mathrm{em} 20$ anos. Os dados relativos ao PNUD estão disponíveis em http://www.undp.org.br/HDR/HDR2002/default.asp, e os divulgados pelo IPEA, em http://www.ipeadata.gov.br. Ambos foram acessados em 31 de julho de 2002. 
parece ser incapaz de "realizar os objetivos a que se propõe", senão por causa da carta recém elaborada, para alguns certamente com sua efetiva contribuição ${ }^{12}$. Todavia, é mais provável que a causa daquele cenário tenha raízes exógenas, uma vez que, na década anterior, nos chamados países centrais em geral, e especialmente na Inglaterra e nos Estados Unidos, tomara fôlego um movimento político transnacional de forte conteúdo econômico, cuja tendência nomeada neoliberal diagnosticou como indispensável um novo receituário para as relações entre os Estados nacionais e entre estes e as sociedades às quais serviam.

Apresentada como solução às emergentes crises de governabilidade ${ }^{13}$ que assolavam tanto o mundo economicamente desenvolvido e democrativamente amadurecido quanto o resto, ainda que por razões distintas, aquela nova concepção das relações político-econômicas, acreditava-se, faria efeitos diferenciados, porém homogeneizadores, para as diversas populações do planeta a despeito de suas respectivas posições geopolíticas. Recorrendo a conceitos de democracia moderna e do liberalismo clássico, cujas existências são, segundo NORBERTO BOBBIO, interdependentes ${ }^{14}$, o neoliberalismo tinha por alvo a universalização do mercado através da globalização econômica, uma vez que no plano jurídico-político cada vez mais se universalizavam os direitos.

Proclamava-se mundo afora, inclusive no plano constitucional (a Constituição Brasileira de 1988 era um exemplo), a terceira, quiçá quarta geração de direitos caracterizadamente universais ${ }^{15}$, cuja efetividade estaria sendo, pelo menos no atual estágio da evolução humana, obstaculizada pelos desequilíbrios provocados pela ingerência dos estados nos mercados. Estes teriam, como ordem social, capacidade de se auto-regular e, consequientemente, poderiam restabelecer o equilibrio enfraquecido pelas excessivas intervenções efetuadas pelas variadas espécies de organização política nacional: os estados socialistas, os capitalistas desenvolvidos (welfare states) e os capitalistas "desenvolvimentistas" 16 .

Por conseguinte, a missão do supramencionado movimento consistia em, após a consolidação nos estados capitalistas desenvolvidos, protagonizar pela via institucional, preferencialmente democrática, reformas imprescindíveis e urgentes no aparelho do Estado, que possibilitassem a retomada da governança ${ }^{17}$, face objetiva da

12 FERREIRA FILHO, Manoel Gonçalves. Constituição e governabilidade: ensaio sobre a (in)governabilidade brasileira. São Paulo: Saraiva, 1995, p. 5.

13 Idem. p. 1-5: PEREIRA, Luiz Carlos Bresser. A Reforma do estado dos anos 90; lógica $e$ mecanismos de controle. Lua Nova, São Paulo, $n^{\circ} 45$, 1998, p. 82-4; BOBBIO, Norberto; MATTEUCCI, Nicola; PASQUINO, Gianfranco. Dicionário de Política. $5^{2}$ ed. Brasília: Unb, 2000. p. 548-50.

14 BOBBIO, Norberto. Liberalismo e democracia. São Paulo: Brasiliense, 2000. p. 36.

15 PEREIRA, Luiz Carlos Bresser. Cidadania e res publica: a emergência dos direitos republicanos. Brasília: ENAP, 1997. (Texto para discussão, $n^{\circ}$ 15). p. 16-7.

16 PEREIRA, Luiz Carlos Bresser. A Reforma do estado dos anos 90; lógica e mecanismos de controle. Lua Nova, São Paulo, ${ }^{\circ} 45,1998$, p. 52.

17 Idem. p. 82-4; MORALES, Carlos Antonio. Nem privado nem estatal: em busca de uma nova estratégia para a provisão de serviços públicos. Revista do Serviço Público, Brasília; ENAP, Ano-49, $n^{\circ} 4,1998$, p. 125-6. 
governabilidade. Do ponto de vista institucional, somente o Estado pode reformar-se a si mesmo, não sendo permitido a nenhuma outra ordem fazê-lo, o que caracterizaria uma revolução ${ }^{18}$.

Com efeito, para evitar revoluções em geral de conteúdo violento, a superação da "crise do Estado" com a reconquista da governança dar-se-ia, segundo os teóricos, através de reformas a serem empreendidas nas suas diversas manifestações as quais poderiam ser caracterizadas por crise fiscal, crise na forma intervencionista do Estado na economia e crise na organização administrativa estatal, sendo certo que visando extirpar esta última, em terras brasileiras resultou a Emenda Constitucional $n^{\circ} 19 / 98$, produzida pela "proposta ... relativa às disposições que regem a administração pública", sobre a qual cabe destacar, no Plano Diretor da Reforma do Estado, dentre as expectativas de "resultados" 19 , aquelas que se referem especialmente ao assunto em tela, ou seja, "incorporar a dimensão da eficiência na administração pública" $e$ "romper com formatos jurídicos e institucionais rígidos e uniformizadores". Nesse contexto a eficiência da administração pública foi definida como "a necessidade de reduzir custos e aumentar a qualidade dos serviços" ${ }^{20}$ ou seja, "a busca de uma relação ótima entre qualidade e custo dos serviços colocados à disposição do público" 21 .

O corpo interministerial, responsável pela elaboração do Plano Diretor, registrou naquele documento a possibilidade de se identificar a atuação do Estado em "quatro setores" 22 assim caracterizados:

1. "NÚCLEO ESTRATÉGICO. Corresponde ao governo, em sentido lato. É o setor que define as leis e as políticas públicas, e cobra o seu cumprimento.(...)";

2. "ATIVIDADES EXCLUSIVAS. É o setor em que são prestados serviços que só o Estado pode realizar. São serviços em que se exerce o poder extroverso do Estado - o poder de regulamentar, fiscalizar, fomentar. Como exemplos temos: a cobrança e fiscalização dos impostos, a polícia, a previdência social básica, o serviço de desemprego, a fiscalização do cumprimento de normas sanitárias, o serviço de trânsito, a compra de serviços de saúde pelo Estado, o controle do meio ambiente, o subsídio à educação básica, o serviço de emissão de passaportes etc.";

18 BOBBIO, Norberto: MATTEUCCI, Nicola; PASQUINO, Gianfranco. Dicionário de Política. $5^{2}$ ed. Brasília: Unb, 2000. p. 1077-8.

19 PEREIRA JUNIOR, Jessé Totres. Da reforma administrativa constitucional. Rio de Janeiro: Renovar, 1999, p. 2-3.

20 BRASIL. Ministério do Planejamento, Orçamento e Gestão. Plano Diretor da Reforma do Estado. Disponível em: http:/www.planejamento.gov.br/gestao/conteudo/publicacoes/plano_diretor/portugues_tudo.htm. Acesso em: 01.08.2002. 2-As Três Formas de Adninistração Pública.

21 BRASIL. Op. cit., 5.2 Setores do Estado e Tipos de Gestão.

22 BRASIL. Ministério do Planejamento, Orçamento e Gestão. Plano Diretor da Reforma do Estado. Disponível em: http:/www.planejamento.gov.br/gestao/conteudo/publicacoes/plano_diretor/portugues_tudo.htm. Acesso em 01.08.2002. 5.1 Os Setores do Estado. 
3. "SERVIÇOS NÃO EXCLUSIVOS. Corresponde ao setor onde o Estado atua simultaneamente com outras organizações públicas não-estatais $e$ privadas. As instituições desse setor não possuem o poder de Estado. Este, entretanto, está presente porque os serviços envolvem direitos humanos fundamentais, como os da educação e da saúde, ou porque possuem 'economias extemas' relevantes, na medida que produzem ganhos que não podem ser apropriados por esses serviços através do mercado. As economias produzidas imediatamente se espalham para o resto da sociedade, não podendo ser transformadas em lucros. São exemplos deste setor: as universidades, os hospitais, os centros de pesquisa e os museus";

4. "PRODUÇÃO DE BENS E SERVIÇOS PARA O MERCADO. Corresponde à área de atuação das empresas. É caracterizado pelas atividades econômicas voltadas para o lucro que ainda permanecem no aparelho do Estado como, por exemplo, as do setor de infra-estrutura. Estão no Estado seja porque faltou capital ao setor privado para realizar o investimento, seja porque são atividades naturalmente monopolistas, nas quais o controle via mercado não é possível, tornando-se necessário no caso de privatização, a regulamentação rígida".

Dos sobreditos setores, para o tema em comento, têm relevância especificamente os serviços não-exclusivos, para os quais o Plano Diretor estabeleceu os seguintes "objetivos" a serem alcançados com a Reforma:

1. "transferir para o setor público não-estatal estes serviços, através de um programa de 'publicização', transformando as atuais fundações públicas em organizações sociais, ou seja, em entidades de direito privado, sem fins lucrativos, que tenham autorização específica do poder legislativo para celebrar contrato de gestão com o poder executivo e assim ter direito a dotação orçamentária";

2. "lograr, assim, uma maior autonomia e uma conseqüente maior responsabilidade para os dirigentes desses serviços";

3. "lograr adicionalmente um controle social direto desses serviços por parte da sociedade através dos seus conselhos de administração";

4. "fortalecer práticas de adoção de mecanismos que privilegiem a participação da sociedade tanto na formulação quanto na avaliação do desempenho da organização social, viabilizando o controle social";

5. "lograr, finalmente, uma maior parceria entre o Estado, que continuará a financiar a instituição, a própria organização social, e a sociedade a que serve e que deverá também participar minoritariamente de seu financiamento via compra de serviços e doações";

6. "aumentar, assim, a eficiência e a qualidade dos serviços, atendendo melhor o cidadão-cliente a um custo menor". ${ }^{23}$

23 BRASIL. Ministério do Planejamento, Orçamento e Gestão. Plano Diretor da Reforma do Estado. Disponível em: http://www.planejamento.gov.br/gestao/conteudo/publicacoes/plano_diretor/portugues_tudo.htm.. Acesso em: 01.08.2002. 6.4 Objetivos para os Serviços Não-exclusivos. 
Com efeito, nova forma de atuação estatal, no setor de serviços não-exclusivos, buscaria a eficiência como resultado da estratégia de "publicização" de certas fundações públicas que, apesar de trasmudadas para organizações sociais, instituições beneficiadas com "maior autonomia" porque subordinadas ao direito privado, continuariam públicas na medida em que, com "autorização especifica do poder legislativo" teriam "direito a dotação orçamentária", cuja necessária participação conjunta de representantes do poder público e da sociedade em "seus conselhos de administração" garantiriam, além do financiamento privado "via compra de serviços $e$ doações", o "controle social direto" da entidade com conseqüente aumento da "qualidade dos serviços".

Destarte, o Plano Diretor da Reforma do Estado definiu organizações sociais ${ }^{24}$ consoante o acima exposto, sendo oportuno fazer a seguinte complementação:

1. são "entidades de direito privado que, por iniciativa do Poder Executivo, obtêm autorização legislativa para celebrar contrato de gestão com esse poder, e assim ter direito à dotação orçamentária";

2. "lei específica" estabelecerá determinadas condições "como, por exemplo, a forma de composição de seus conselhos de administração, prevenindo-se, deste modo, a privatização ou a feudalização dessas entidades";

3. com a participação direta da sociedade, apesar dos "recursos orçamentários", se busca suplementar a obtenção de "outros ingressos através da prestação de serviços, doações, legados, financiamentos etc", ou complementar o orçamento daquelas instituições, uma vez que, consoante "a maior parceria com a sociedade", esta "deverá financiar uma parte menor mas significativa dos custos dos serviços prestados";

4. "a transformação dos serviços não-exclusivos estatais em organizações sociais se dará de forma voluntária, a partir da iniciativa dos respectivos ministros, através de um Programa Nacional de Publicização": e

5. "terão prioridade os hospitais, as universidades e escolas técnicas, os centros de pesquisa, as bibliotecas e os museus".

Sem embargos, o Plano Diretor é ambiguo ao dar à "publicização" ora a idéia simplista de "iniciativa do Poder Executivo" em conceder "autorização legislativa para celebrar contrato de gestão", ora o caráter de processo complexo pelo qual serão transformados "atuais fundações públicas em organizações sociais, ou seja, em entidades de direito privado".

Por conseguinte, consoante o até aqui exposto, a instituição das organizações sociais parece se relacionar prioritariamente ao princípio da eficiência, quer pelo comando constitucional reformado que explicita sua necessária observância na atuação da administração pública direta e indireta - e o Poder Público atuando como uma das partes do contrato de gestão deverá ser eficiente - , quer pelo pressuposto aporte suplementar de recursos não originários dos cofres públicos para financia- 
mento dos serviços não-exclusivos, não obstante, pelo menos saúde (art. 196, CF/88) e educação (art. 205, art. 208, inciso V, C.F./88), serem deveres primários do Estado.

A Lei ${ }^{\circ} 9.637 / 98$ surgiu, conforme determinação do Plano Diretor, antes mesmo de aprovada a Reforma pelo Poder Legislativo, para permitir que, com a instituição das organizações sociais, se pavimentasse o caminho que conduziria a Administração Pública ao definitivo domínio, nos serviços não-exclusivos, do princípio da eficiência.

\section{Das observações acerca da Lei $n^{\circ} 9.637 .98$}

Em 26 de julho de 1996, após a aprovação pelo Presidente da República no final do ano de 1995, prefaciado praticamente pela mesma exposição de motivos ${ }^{25}$, o Plano diretor da Reforma do Estado foi formalmente apresentado ao Plenário do Senado Federal, dando início ao processo legislativo do qual resultou, em 4 de junho de 1998, a Emenda Constitucional $n^{\circ} 19$. Contudo, em 9 de outubro de 1997, "no uso da atribuição que the confere o art. 62 da Constituição", considerando a relevância e urgência das organizações sociais para aquele tema, o Chefe do Executivo Federal submeteu ao Congressso Nacional a Medida Provisória $\mathrm{n}^{\circ} 1.591$ que, dentre outras coisas, dispunha sobre "a qualificação de entidades como organizações sociais" e "a criação do Programa Nacional da Publicização", ambas proposições esboçadas no supramencionado plano. Reeditada várias vezes. em 15 de maio de 1998, sob o $\mathrm{n}^{\circ} 1.648$, a MP foi transformada na Lei $\mathrm{n}^{\circ} 9.637$, vindo a ser objeto argüições de inconstitucionalidade, ainda de pendentes ${ }^{26}$, impetradas por setores da sociedade civil em socorro a diversos princípios constitucionais ${ }^{27}$, cabendo acrescentar pressuposta violação à competência executiva comum (art. 23) do Poder Público no que ser refere a cuidar da saúde (inciso II) e a proporcionar acesso à cultura, à educação e à ciência (inciso $\mathrm{V}$ ).

Não obstante a possibilidade de lesão constitucional, o sobredito episódoio evidencia que o processo de "publicização" dos serviços não-exclusivos, alvo das organizações sociais, poderia ser efetivado independentemente da Reforma, nela figurando como pré-requisito no qual o princípio da eficiência. capturado pelo contrato de gestão (do art. $5^{\circ}$ ao art. 10 da Lei $n^{\circ} 9.637 / 98$ ), seria o traço comum.

À semelhança do Plano Diretor, o texto legal supramencionado é ambíguo. De um lado traduz à idéia de "publicização" como o processo pelo qual o "Poder Executivo poderá qualificar como oragnizaçōes sociais pessoas jurídicas de direito

25 PEREIRA. Luiz Carlos Bresser. Exposição no Senado sobre a Reforma da Administração Pública. Brasília: MARE, 1997. (Cadernos MARE da reforma do estado; $\mathrm{n}^{\circ} 3$ ).

26 Ação Direta de Inconstitucionalidade $n^{\circ} 1.923-5$ (Medida Liminar indeferida). Requerente: Partido dos Trabalhadores - PT e Partido Democrático Trabalhista - PDT. Ação Direta Inconstitucionalidade $n^{\circ} 1.943-1$. Requerente: Conselho Federal da Ordem dos Advogados do Brasil. 27 PAES. José Eduarto Sabo. Fundações e entidades de interesse social: aspectos juridicos, administrativos, contábeis e tributários. Brasília: Brasília Jurídica, 2001. p. 86-8. 
privado, sem fins lucrativos, cujas atividades sejam dirigidas ao ensino, à pesquisa científica, ao desenvolvimento tecnológico, à proteção e preservacão do meio ambiente, à cultura e à saúde" (art. $1^{\circ}$ ); de outro que "publicização" consiste em "assegurar a absorção de atividades desenvolvidas por entidades ou órgãos públicos da União, que atuem nas atividades referidas no art. $I^{\circ}$, por organizações sociais" (art. 20).

A falta de objetividade quanto à natureza da novel instituição conduziu a doutrina a formular diversas teses caracterizadas por justificações dos mais diferentes matizes, das quais se registram as seguintes:

1. ODETE MEDAUAR inclui as organizações sociais entre os "entes com situação peculiar" que "vêrm gerando dúvidas e críticas, em virtude, principalmente, da preocupação com a preservação do patrimônio público e com a gratuidade e universalidade de acesso a serviços públicos" 28 ;

2. ROMEU FELIPE BACELLAR entende que "a proposta da Administração Pública é de que assuma uma forma, uma aparência de fundação, mas não a fundação a que nós estamos acostumados"29

3. MARIA SYLVIA ZANELLA DI PIETRO esclarece que “..., surgem agora as chamadas organizações sociais... por não terem patrimônio próprio nem sua própria fonte de receita, elas se utilizam do patrimônio público ... elas não têm sede própria e se instalam dentro das repartições públicas; os servidores públicos prestam serviços a essas entidades, tendo seus salários complementados pelas mesmas" 30

4. LUCIANO FERRAZ percebe que "o objetivo é fugir às amarras do regime jurídico administrativo, eis que as organizações sociais são consideradas entidades 'públicas não estatais', não integrantes da Administração indireta (...) - continuarão a desempenhar os mesmos préstimos de outrora, agora sob novo rótulo, escapando às 'ingerências' do regime jurídico administrativo" 31

5. para JOSÉ EDUARDO SABO PAES organizações sociais "são um modelo ou uma qualificação" ou "objetivam ser um modelo de parceria entre o Estado e a sociedade, mas não constituem uma nova pessoa juridica" ${ }^{32}$;

28 MEDAUAR, Odete. Direito Administrativo Moderno. $6^{\text {a }}$ ed. São Paulo: Revista dos Tribunais, 2002. p. 112 e 117.

29 BACELLAR, Romeu Felipe. A administração pública - tendências atuais (Reforma Administrativa). Palestra proferida em 23.10.97, por ocasiāo do XIX Congresso dos Tribunais de Contas do Brasil, realizado no Rio de Janeiro. Disponível em: http://www.tce.rj.gov.br/revista/artigos/r38c001.htm. Acesso em: 29.10.2001.

30 DI PIETRO, Maria Sylvia Zanella. Adefesa do cidadāo e da res publica. Revista do Serviço Público, Brasília: ENAP, Ano 49, n², 1998, p. 128.

31 FERRAZ, Luciano. O Estado Gerencial e a Lei de Licitações Públicas. Interesse Público, Sapucaia do Sul, n 3, 1999, p. 43.

32 PAES, José Eduardo Sabo. Fundações e entidades de interesse social: aspectos jurídicos, administrativos, contábeis e tributários. Brasília: Brasília Jurídica, 2001, p. 80. 
6. JESSÉ TORRES PEREIRA NUNES declara ser "qualificação de pessoa jurídica de direito privado ... novo rótulo para designar a entidade que cooperará com o poder público na realização de atividades ${ }^{1,33}$;

7. DIOGO DE FIGUEIREDO MOREIRA NETO firma entendimento de que " um novo quadro para o fomento no Brasil, incentivando a criação de entes intermédios pela sociedade, foi inaugurado com a "possibilidade das entidades criadas ... se habilitarem à qualificaçāo como organização social", sendo esta qualificação "ato administrativo unilateral que é outorgado discricionariamente, sempre que a associação habilitante for aprovada quanto à conveniência e oportunidade dessa admissão, ao novo 'status', por dois órgãos federais" 34 ;

8. finalmente, para PAULO MODESTO "as organizaçōes sociais representam uma forma de parceria do Estado com as instituiçoes privadas de fins públicos (perspectiva ex parte principe) ou, sob outro ângulo, uma forma de participação popular na gestão administrativa (perspectiva ex parte populi) ... não significa apresentar uma estrutura jurídica inovadora, mas possuir um título jurídico especial, conferido pelo Poder Público em vista do atendimento de requisitos gerais de constituição e funcionamento previstos expressamente em lei" 35

Mostra-se razoável justificar tamanha diversidade pelo caráter ambíguo da lei em tela, uma vez que, na doutrina, se está longe de ver pacificado, ou melhor, longe de se encontrar um entendimento, sequer majoritário, acerca do que sejam as organizações sociais.

Contudo, aparentemente no âmbito do Poder Público, todas as ações da Administração autorizam a crença de que a ambigüidade anteriormente mencionada se resolveu consoante a transformação de "entidades ou órgãos públicos da União, que atuem nas atividades referidas no art. $1^{\circ}$, em "pessoas jurídicas de direito privado", cujas qualificações como organizações sociais são sucedâneos imprescindíveis, inerentes a quaisquer processos análogos aos que lograram concretizar "as extinções e a absorção de atividades e serviços" estabelecidas nos art. 21 e 22 daquela lei ${ }^{36}$.

33 PEREIRA JR., Jessé Torres. Da reforma administrativa constitucional. Rio de Janeiro: Renovar. 1999 , p. 46.

34 MOREIRA NETO, Diogo de Figueiredo. Mutações do Direito Administrativo. $2^{\mathrm{a}}$ ed. Rio de Janeiro: Renovar, 2001. p. 194-5.

35 MODESTO, Paulo. Reforma administrativa e marco legal das organizações sociais no Brasil - as dúvidas dos juristas sobre o modelo das organizaçāos sociais. Revista Diálogo Jurídico, Salvador, CAJ - Centro de Atualização Jurídica, v. I, $\mathrm{n}^{\circ}$ 9, dezembro, 2001. Disponível em: http://www.direitopublico.com.br. Acesso em: 01.08.2002.

36 (1) Decreto $n^{\circ} 2.405$, de 26.11.1997, "qualifica como organização social a Associação Brasileira de Tecnologia de Luz Sincrotron -- ABTLUS e autoriza a absorção das atividades do extinto Laboratório Nacional de Luz Síncrotron pela entidade referida". Disponível em: http://wwwt.senado.gov.br/legbras. Acesso em 31.08.2002; (2) Decreto $\mathrm{n}^{\circ} 2.442$, de 23.12.1997, "qualifica como organização social a Associação de Comunicação Educativa Roquette Pinto - ACERP e autoriza 
Entende SONIA RABELLO DE CASTRO que, "embora o direito possa dar os limites, os objetivos e a forma das ações executivas, a ação do governo, materializada pela execução das políticas públicas, terá sempre conteúdo amplo, isto é, não exclusivamente restrito a previsões normativas específicas" ${ }^{37}$. Tal "conteúdo mais amplo" é o que legitima a discricionariedade administrativa, razão pela qual DIOGO DE FIGUEIREDO MOREIRA NETO conceitua discricionariedade como a qualidade da competência legal da Administração Pública "para definir, abstrata ou concretamente o resíduo de legitimidade necessário ... à sua execução", sendo certo que "a definição de resíduo de legitimidade indica que o exercício da discricionariedade tem natureza material de uma opção política" ${ }^{38}$.

Assim, prima facie, ao estabelecer que o "Poder Executivo poderá qualificar como organizações sociais pessoas jurídicas de direito privado, em fins lucrativos, cujas atividades sejam dirigidas ao ensino, à pesquisa científica, ao desenvolvimento tecnológico, à proteção e preservação do meio ambiente, à cultura e à saúde", o ant. $I^{\circ}$ instrumentaliza $^{39}$ a Administração Pública com o poder discricionário, cuja

a absorção das atividades da extinta Fundação Roquette Pinto.”. Disponível em: http://wwwt.senado.gov.br/legbras. Acesso em 31.08.2002; (3) Decreto de 18.03.1999, " qualifica como organização social a Associação Brasileira para o Uso Sustentável da Biodiversidade da Amazônia - BIOAMAZÔNIA" que consoante "Ata de Constituição da Associação Brasileira para o Uso Sustentável da Biodiversidade da Amazônia - BIOAMAZÔNIA" foi constituída "Aos 4 (quatro) dias do mês de agosto de 1998 ...". Disponível em: http://www.bioamazonia.org.br. Acesso em 31.08.2002; (4) Decreto de 4.06.1999, "qualifica como Organização Social o Instituto de Desenvolvimento Sustentável Mamirauá - IDSM", o qual "...foi criado em maio de 1999 com o objetivo de dar continuidade de implementação que já vinham sendo realizados pelo Projeto Mamirauá". Disponível em: "http://www.mamiraua.org.br/1-1.html. Acesso em 31.08..2002; (5) Decreto $n^{\circ} 3.605$, de 20.09.2000, "qualifica como Organização Social a Associação Instituto Nacional de Matemática Pura e Aplicada - IMPA", tendo sido complementado pelo Decreto ${ }^{\circ} 3.703$, de 27.12.2000 o qual autoriza " a absorçāo das atividades do Instituto de Matemática Pura e Aplicada - IMPA pela entidade referida". Disponivel em: http://wwwt.senado.gov.br/legbras. Acesso em 31.08.2002; (6) Deceto $n^{\circ} 4.077$, de 9.01.2002, "qualifica como Organização Social a Associação Rede Nacional de Ensino e Pesquisa - RNP", cujo Estatuto data de 8 de outubro de 1999. Disponível em: http://www.sbc.org.br/documentos/estatrnp.html. Acesso em 31 ago 2002; (7) Decreto $\mathrm{n}^{\circ} 4.078$, de 9 de janeiro de 2002, "qualifica como Organização Social o Centro de Gestão e Estudos Estratégicos", que consoante a "Ata de Constituiçâo do Centro de Gestão e Estudos Estratégicos" foi constituída "Aos vinte dias do mês de setembro de 2001 ...". Disponível em: http://www.cgee.org.br. Acesso em 31 ago 2002.

37 CASTRO, Sonia Rabello de. Habitaçāo: direito e governança. Revista de Administração Pública, Rio de Janeiro: FGV, vol. 35 (5), p. 111 -26, jul/ago, 2001.

38 MOREIRA NETO, Diogo de Figueiredo. Legitimidade e discricionariedade: novas reflexōes sobre os limites e controle da discricionariedade. $1^{\star 2}$ ed. Rio de Janeiro: Forense, 1989. p. 22; em sentido semelhante MEDAUAR, Odete. Direito Administrativo Moderno. $6^{2}$ ed. São Paulo: Revista dos Tribunais, 2002. p. 135; MELLO, Celso Antônio Bandeira de. Elementos de Direito Administrativo. $3^{\star}$ ed. São Paulo: Malheiros, 1992. p. 291: "composição da vontade legal pelo administrador".

39 MEIRELLES, Hely Lopes. Direito Administrativo Brasileiro. $22^{2}$ ed. São Paulo: Malheiros, 1997, p. 100-1; MELLO, Celso Antônio Bandeira de. Elementos de Direito Administrativo. 3" ed. São Paulo: Malheiros, 1992. p. $21-2$. 
natureza política, além de conduzir à afirmação de inexistência de discricionariedade técnica ${ }^{40}$ ou a restringir esta existência a escolhas objetivas e despolitizadas ${ }^{41}$, se apóia nos juízos de conveniência e oportunidade e se subordina aos princípios da realidade e da razoabilidade ${ }^{42}$, os quais buscam viabilizar o atendimento do interesse público relativamente vinculado.

Todavia, a mens legis do próprio diploma em comento, "tornar ... muito mais eficientes os serviços sociais competitivos" $"$, privilegia o princípio de eficiência administrativa cuja essência, consoante o Plano Diretor, é objetivamente técnica, do qual resulta o drama endógeno daquela norma, uma vez que, como preleciona CELSO ANTÔNIO BANDEIRA DE MELLO, "existe ... uma incompatibilidade lógica absoluta entre discricionariedade e objetividade" 44.

Do acima exposto, a despeito de não configurar antinomia, cujo entendimento clássico pode ser expresso como a "presença de duas normas conflitantes sem que se possa saber qual delas deverá ser aplicada no caso singular" ${ }^{45}$, subsiste a possibilidade de espécie sofisticada de fraude à lei, "meio pelo qual o agente consegue alcançar um resultado proibido através de atos que não contrariam as palavras da lei, mas contrariam seu sentido"46

A fraus legis parece ser da gênesis da noticiada Reforma, uma vez que, s.m.j., FRANCISCO MAURO DIAS criticando a proposta relativa a nulificação de "situações jurídicas definitivas e legitimamente constituída de acumulação remunerada" de servidores públicos, em trabalho acadêmico de sua lavra, conclui pela possibilidade de "a Reforma do Estado se viabilizar mediante emenda que desconsidere a vedação da retroatividade retroativa onerosa insculpida no inciso XXXVI do art. $5^{\circ}$ da Constituição, nascerá, destarte, sob o sino de uma 'fraus constitutioni'."47

A solidez do princípio da reserva legal, tornando proibido, para o Estado, tudo aquilo que não estiver permitido em lei, amplifica a necessidade de utilizar a própria lei como meio de violação. Daí a extensão das sobreditas concepções doutrinárias no tocante às organizações sociais.

40 MEIRELLES, Hely Lopes. Op. cit., 1997. p. 91.

41 MEIRELLES, Hely Lopes. Idem: MOREIRA NETO, Diogo de Figueiredo. Mutações do Direito Administrativo. $2^{\mathrm{a}}$ ed. Rio de Janeiro: Renovar, 2001. p. 128; MEDAUAR, Odete. Direito Administrativo Moderno. 6a ed. São Paulo: Revista dos Tribunais, 2002. p. 136.

42 MOREIRA NETO, Diogo de Figuciredo. Legitimidade e discricionariedade: novas reflexōes sobre os limites e controle da discricionariedade. $1^{2}$ ed. Rio de Janeiro: Forense, 1989. p. 33-41; CAETANO, Marcello. Manual de Direito Administrativo. $10^{2}$ ed. Lisboa: Almedina. Tomo I. 2001. p. 490-1.

43 BRASIL. Ministério do Planejamento, Orçamento e Gestão. Plano Diretor da Reforma do Estado. Disponível em: http://www.planejamento.gov.br/gestao/conteudo/publicacoes/plano_diretor/portugues_tudo.htm. Acesso em: 01.08.2002.6 - Objetivos.

44 MELLO, Celso Antônio Bandeira de. Op. cit., p. 289.

45 DINIZ, Maria Helena. Conflito de normas. $3^{2}$ ed. São Paulo: Saraiva, 1998. p. 19.

46 PEREIRA, Regis Velasco Fichtner. A fraude à lei. Rio de Janeiro: Renovar, 1994, p. 15.

47 DIAS. Francisco Mauro. Estado de direito, direitos humanos (direitos fundamentais), segurança jurídica e Reforma do Estado. Revista Ciências Sociais/U.G.F., Rio de Janeiro, Edição Especial, 1997. p. 274-5. 
O Plano Diretor (1) ao restringir a ação do Estado ao setor estratégico e de serviços exclusivos, (2) recomendando ao Poder Público transferir à sociedade civil a execução dos serviços não-exclusivos, (3) concebeu outra eficiência administrativa como um novo critério fundamental ${ }^{48}$. Contudo, a Administração Pública foi orientada a fazer aquela transferência "de forma voluntária, a partir da iniciativa dos respectivos ministros" através das organizações sociais, priorizando "os hospitais, as universidades e escolas técnicas, os centros de pesquisa, as bibliotecas e os museus". Tão complexa "operacionalização ... será feita por um Conselho Nacional de Publicizaçāo, de caráter interministerial" "49.

Tanto ao Plano Diretor quanto na Lei $n^{\circ} 9.637 / 98$, consoante a prévia determinação por parte do setor estratégico (político) acerca da composição do setor de serviços competitivos (não político), este subordinado ao princípio da eficiência e constituído das atividades "dirigidas ao ensino, à pesquisa cientifica, ao desenvolvimento tecnológico, à proteção e preservação do meio ambiente, à cultura e à saúde", ou seja, numerus clausus caracterizadores deste setor, restariam à sobredita discricionariedade do art. $1^{\circ}$ os limites relativos à identificação da "pessoas jurídicas de direito privado, sem fins lucrativos".

Eventuais falhas no exercício do poder discricionário por um lado, e a natureza pública do serviço não-exclusivo por outro, autorizam a proteção legal determinada nos arts. $2^{\circ}$, inciso I, alínea “ $i$ ”, e 16, ambos relativos ao patrimônio público, e nos arts. $3^{\circ}$ e $4^{\circ}$, relacionados à composição dos conselhos de administração das organizações sociais, "prevenindo-se, deste modo, a privatização ou a feudalização dessas entidades" por desvio de finalidade.

Com efeito, se afastadas as possibilidades de inconstitucionalidade e fraude à lei, resta a aparência de que, na implantação das organizações sociais, ao invés da discricionariedade, é o arbítrio do administrador público ${ }^{50}$ que tem prevalecido.

Estão a legitimar tal perspectiva a comprovada inexistência de qualquer decreto constituindo o sobredito Conselho Nacional de Publicização, somada aos improváveis processos administrativos indicadores da autonomia da vontade das "entidades privadas" expressa no art. $2^{\circ}$, e ao fato de a instituição das organizações sociais por ter caráter principiológico, ou melhor, por aproveitar com exclusividade o princípio da eficiência, não dar azo à voluntariedade do agente público, uma vez que esta, como foi visto, não diz respeito à escolha dos serviços competitivos, mas a fixação dos fins lucrativos ou não das entidades privadas habilitantes.

48 BRASIL. Ministério do Planejamento, Orçamento e Gestão. Plano Diretor da Reforma do Estado. Disponível em: http://www.planejamento.gov.br/gestao/conteudo/publicacoes/plano_diretor/portugues_tudo.htm. Acesso em: 01.08.2002. 5.2 Setores do Estado e Tipos de Gestão.

49 BRASIL. Op. cit., 8.1.3 Organizações Sociais e Publicização.

50 MEIRELLES, Hely Lopes. Direito Administrativo Brasileiro. 22 ed. São Paulo: Malheiros, 1997. p. 103; MELLO, Celso Antônio Bandeira de. Elementos de Direito Administrativo. $3^{\star}$ ed. São Paulo: Malheiros, 1992. p. 292. 
Nos serviços públicos não-exclusivos, assim definidos pelos próprios idealizadores da Reforma, o princípio privilegiado não é a efetividade mas a eficiência ${ }^{51}$. Esta é resultante da relação ótima entre os elementos custo e benefício, os quais, por possuírem natureza objetiva, não se encontram sujeitos ao poder discricionário da Administração. Por isso, no embate entre a discricionariedade e a eficiência, resulta modificada a primeira que se transmuda em arbítrio, e, então ao arrepio da lei, inquina de vícios seus atos comissivos ou não.

Consoante o até aqui exposto, convém ressaltar que a eficiência é o único motivo para o Poder Público transferir à sociedade civil a execução dos serviços não-exclusivos, com a devida proteção legal contra possíveis desvios de finalidade. Consubstancia a lei em tela, a mesma justificação registrada no Plano Diretor para o princípio de eficiência, cuja natureza não deixa espaço ao aspecto político onde este não deva ser considerado. Todavia, falhas de diagnóstico no setor estratégico quanto à natureza dos serviços públicos nomeados não-exclusivos acarretariam efeitos semelhantes aos acima verificados, porém, com consequiências mais profundas porque tornariam inconstitucional a própria lei.

\section{Da natureza dos serviços não-exclusivos}

$\mathrm{Na}$ Exposição no Senado sobre a Reforma da Administração Pública, no que se refere às chamadas de atividades não-exclusivas de Estado, BRESSER PEREIRA começa seu discurso afirmando que sua "proposta é de que a forma de propriedade dominante nesse setor deve ser a pública não-estatal." Na continuidade daquele ato, o expositor explica que "no capitalismo contemporâneo, as formas de propriedade relevantes não são apenas duas, como geralmente se pensa e como a divisão clássica do Direito entre Direito Público e Privado sugere - a propriedade privada e a pública - mas são três: (1) a propriedade privada, voltada para a realização do lucro (empresas) ou do consumo privado (familias); (2) a propriedade pública estatal e. (3) a propriedade pública não-estatal. "52

Naquela proposta, dois são os propósitos a destacar: um explícito - afirmar o já pacífico entendimento de que o público não se restringe ao estatal -, inclusive porque o primeiro é o continente e o segundo, o conteúdo; e outro implícito e certamente mais importante - convencer que era chegada a hora dos princípios do direito serem submetidos aos princípios da economia, submetendo assim, segundo aquele entendimento, o Estado à sociedade.

Da segunda intenção apontada resultou que, após a Emenda Constitucional $\mathrm{n}^{\circ}$ 19/98, passou a figurar, no texto político de forma explícita (art. 37), entre os

51 BRASIL. Ministério do Planejamento, Orçamento e Gestão. Plano Diretor da Reforma do Estado. Disponível em: http://www.planejamento.gov.br/gestao/conteudo/publicacoes/plano_diretor/portugues_tudo.htm. Acesso em: 01.08.2002. 5.2 Setores do Estado e Tipos de Gestão.

52 PEREIRA, Luiz Carlos Bresser. Exposição no Senado sobre a Reforma da Administração Pública. Brasília: MARE, 1997. (Cadernos MARE da reforma do estado; ${ }^{\circ}$ 3). p. 28. 
princípios genéricos da legalidade, impessoalidade, moralidade e publicidade, o princípio da eficiência da administração pública direta e indireta, sobre o qual, se faz oportuno trazer à colação registro feito por PEREIRA JÚNIOR, no qual agudamente observa que na "presença do princípio da eficiência na Administração Pública, seria legítimo suspeitar-se de que sua inserção no texto constitucional cumpre propósito ideológico, ajurídico, o que não o desqualifica para figurar na Constitiuição - que é antes documento político do que jurídico -, contudo deve alertar o intérprete para outras possiveis inferências." 53 .

Não obstante PAULO MODESTO discordar expressamente desse entendimento ${ }^{54}$, mesmo tendo sido contrário " a introdução dessa alteração na cabeça do art. 37 " 55 , vem em socorro ao pensamento de PEREIRA JÚNIOR a grande probabilidade de que tal tenha sido o intuito da inserção, na medida em que, independentemente de nos discursos os promotores da reforma firmarem posição em contrário, são claros os sinais de que as diretrizes relativas ao Plano Diretor da Reforma do Estado constituem fortes viés econômico pró-mercado, indicando o propósito, registrado acima, de submeter o direito à economia.

O cientista político ANDRÉ BORGES consigna em trabalho de sua lavra que alguns autores identificam quatro correntes econômicas neoliberais ${ }^{56}$; o monetarismo, a escola austríaca, a teoria da escolha pública e a teoria das expectativas racionais; esta última frequientemente criticada por BRESSER PEREIRA em suas declarações ${ }^{57}$.

Entendem outros dois pesquisadores, CHRISTINA W. ANDREWS e ALEXANDER KOUZMIN, que o "discurso da nova administração pública", mesmo tentando, nâo consegue disfarçar sua inclinação teórica vinculada à teoria da escolha pública, cujos pressupostos do interesse individual, das interações sociais como trocas no mercado e do individualismo metodológico ${ }^{58}$, dentre outros prejuízos possíveis, não favorecem a consecução dos objetivos fundamentais inscritos na Constituição Cidadã, art. $3^{\circ}$, relativos à construção de uma sociedade livre, justa e solidária (inciso I), ao desenvolvimento nacional (inciso II) e à erradicação da pobreza (inciso III).

53 PEREIRA JR., Jessé Torres. Da reforma administrativa constitucional. Rio de Janeiro: Renovar, 1999. p. 44.

54 MODESTO, Paulo. Notas para um debate sobre o princípio constitucional da eficiência. Interesse Público, Sapucaia do Sul, $\mathrm{n}^{\circ}$ 7, 2000. p. 71.

55 Idem. p.72.

56 BORGES, André. Democracia vs. Eficiência: a teoria da escolha pública. Lua Nova, São Paulo, $\mathrm{n}^{\circ}$ 53, 2001. p. 159 (nota).

57 PEREIRA, Luiz Carlos Bresser. A Reforma do estado dos anos 90: lógica e mecanismos de controle. Lua nova, São Paulo, $\mathrm{n}^{\circ} 45,1998$, p. 84-6; Idem. Cidadania e res publica: a emergência dos direitos republicanos. Brasília: ENAP, 1997. (Texto para discussão, $n^{\circ} 15$ ). p. 14-5.

58 ANDREWS, Christina W.; KOUZMIN, Alexander. $O$ discurso da nova administração pública. Lua Nova, São Paulo, ${ }^{\circ} 45$, p. 98, 116-24. 
Destarte, a constatação de que "mercados livres não surgem por si sós simplesmente porque eles vão contra o ordenamento natural das sociedades", assim também, "a centralização burocrática no aparelho do Estado e o crescimento dos métodos administrativos de intervenção são a contrapartida necessária à consecução de ambicioso projeto de engenharia social. ... a história mostra que o processo de democratização do Estado capitalista resultou no surgimento de uma economia social de mercado, onde o laissez-faire foi abandonado em favor da extensa regulação e desmercantilização da economia privada". 54

Mesmo na antiguidade, mutatis mutandis, esse era também o entendimento de ARISTÓTELES ${ }^{60}$, o que indica a regularidade humana no tocante a formações políticas básicas $^{61}$.

Consoante a tensão relacionada à instituição de mercados livres, que o são, segundo o entendimento expressado, graças às intervenções estatais, resulta o estabelecimento de princípios de eficiência os quais reduzem a vida política, no sentido aristotélico, a verdades incontestáveis que só os economistas são capazes de alcançar. Creditando à neutralidade e infalibilidade da ciência econômica e de suas posições sucesso garantido, assumem a responsabilidade diretiva na construção de uma sociedade com mercados desregulamentados, orçamentos públicos equilibrados e moedas estáveis, com vistas à proteção da res publica, conforme se constata no depoimento de BRESSER PEREIRA:

"Constituindo-se principalmente de um fluxo de receitas tributárias, a res publica é um bem econômico comum fundamental. Os economistas, apesar de todo o seu individualismo que os leva freqüentemente a desacreditar da possibilidade de ação coletiva, estão profissionalmente voltados para a utilização ótima de recursos escassos. Sua permanente tentação está em acreditar que os mercados sejam capazes de realizar autonomamente essa tarefa. Entretanto, quando a intervenção do Estado se mostra inevitável, os economistas - e não apenas os que trabalham para o Estado - dispõe do instrumental para desenvolver métodos razoavelmente rigorosos de avaliação das políticas públicas pelas quais protegem o patrimônio econômico público. Logram, assim, critérios para distinguir qual é a intervenção do Estado no econômico e no social que é legítima e qual não é." 62

5y BORGES, André. Democracia vs. Eficiência: a teoria da escolha pública. Lua nova. São Paulo, $\mathrm{n}^{\circ}$ 53, 2001. p. 165-8.

60 ARISTÓTELES. Política. São Paulo: Martin Claret, 2001. (Coleção A Obra-Prima de Cada Autor, 61), p. 11-5; CHÂTELET. François. DUHAMEL, Olivier, PISIER-KOUCHNER. Évelyne. História das Idéias Políticas. Rio de Janeiro: Jorge Zahar, 1994, p. 14; BOBBIO. Norberto. Estado, governo e sociedade: para uma teoria geral da politica. $7^{\mathrm{a}}$ ed. Rio de Janeiro: Paz e Terra, 1999. p. 24-5.

61 BOBBIO, Norberto. O futuro da democracia: uma defesa das regras do jogo. $5^{\mathbf{a}}$ ed. Rio de Janeiro: Paz e Terra, 1992, p. 22-3.

62 PEREIRA, Luiz Carlos Bresser. Cidadania e res publica: a emergência dos direitos republicanos. Brasília: ENAP, 1997. (Texto para discussão, n 15). p. 29. 
Esta compreensão dá legitimidade à retórica da eficiência praticamente como um fim em si mesmo, a ponto de se desconsiderar a própria natureza das coisas, tão cara ao direito, enquanto garantidor da ordem, da segurança e da justiça.

Portanto, a árdua relação jurídica entre os atores sociais que, ao longo dos últimos duzentos anos, a despeito dos ensaios promovidos pelos gregos com a polis ${ }^{63}$ construirá a forma mais elaborada de estrutura de poder, responsável pelo crescimento econômico sem precedentes no período, - a organização estatal moderna independentemente de contribuição inequívoca prestada à formação de mercados livres ${ }^{64}$, deveria ser subvertida exatamente porque o Estado não daria conta dos encargos que fora assumindo durante este tempo. Todavia, além do amplo crescimento econômico, o surgimento da moderna organização política marcou também, a despeito das diversas concepções formalizadas, o estágio no qual foi lançada a idéia de humanidade centrada no indivíduo e não na sociedade, criando em potência a "garantia institucional" 65 para "certos direitos inatos" 66 uma vez que "a finalidade de toda associação política é a conservação dos direitos naturais e imprescritíveis do homem" $"$ ?

FRANCESCO CARNELUTTI ensina:

"A idéia do direito e a idéia do Estado estão ... intimamente relacionadas: não há Estado sem direito e nem direito sem Estado. Além do mais, Estado $e$ direito não são a mesma coisa, como alguns ensinaram, com um erro análogo ao de quem confundisse o corpo com a vida. ... A comparação nos leva ... a compreender que não mais do Estado deriva o direito, e sim o Estado do direito. O Estado, isto é, a estabilidade da sociedade, é um produto, e até o produto do direito. $" 68$.

O Estado moderno que começara liberal havia tomado, por conta dos encargos assumidos no rumo à concretização de sua finalidade, a atual forma de Estado Democrático de Direito, exatamente porque os direitos já declarados, portanto reconhecidos, precisavam se tornar realidade ${ }^{69}$.

63 JAEGER, Werner Wilhelm. Paidéia: a formaçāo do homem grego. $3^{a}$ ed. São Paulo: Martins Fontes, 1995, p. 106-7.

64 SANTOS, Boaventura de Sousa. Para uma reinvençāo solidária e participativa do Estado. In: PEREIRA, Luiz Carlos Brresser, WILHEIM. Jorge; SOLA, Lourdes. (Org.) Sociedade e Estado em transformação. São Paulo: Editora UNESP; Brasília; ENAP. 1999. p. 249; BORGES, André. Democracia vs. Eficiência; a teoria da escolha pública. Lua Nova. São Paulo, n 53, 2001, p. 165-6. 65 COMPARATO, Fábrio Konder. A afirmaçāo histórica dos direitos humanos. $2^{2}$ ed. São Paulo: Saraiva, 2001, p. 88-9: em referência ao "BILL OF RIGHTS", Inglaterra, 1689.

66 Idem. p. 112: reprodução do texto da Declaração de Direitos da Virgínia. USA, 1976.

67 Idem. p. 152: reprodução do texto da Declaração de Direitos do Homem e do Cidadão, França, 1789.

68 CARNELUTTI, Francesco. Como nasce o direito. Belo Horizonte: Lider Cultural Jurídica, 2001. p. 53.

69 BOBBIO, Norberto. A era dos direitos. Rio de Janeiro: Campus. 1996, p. 25. 
Outrossim, hodiernamente, na parte do planeta econômica e politicamente mais desenvolvida, os Estados capitalistas avançados conseguiram concretizar, senão todos, pelo menos grande parte dos direitos do homem. Naquelas áreas, Estado, mercado e a sociedade são fortes a tal ponto que da crise fiscal do primeiro emergiu uma sociedade civil com capacidade para assumir ${ }^{70}$, quando o Estado não o fizesse, responsabilidades inatas aos Poder Público, cuja existência se resolve na conservação dos direitos naturais e imprescritiveis do homem.

Com efeito, parece que a divisão clássica do Direito entre Direito Público e Privado teve por objetivo consolidar a idéia de interesse público ${ }^{71}$ inicialmente referenciado às liberdades negativas (direitos de primeira geração), garantias pelo Estado liberal; em segunda etapa se liga às liberdades positivas (direitos de segunda geração) resultado de prestações diretas do Estado social; e hoje se encontra irremediavelmente vinculado ao respeito à dignidade humana (direitos de terceira geração e unidade e universalização de direitos) ${ }^{72}$, cuja consecução é tarefa do Estado Democrático de Direito, marcando a definitiva transição do individualismo para a individualidade ${ }^{73}$.

Portanto, o interesse público não teria se constituído como tal sem a figura do Direito Público o protegendo através do Estado. Nisso reside a umbilical ligação entre Estado e interesse público, na qual este é o fim e aquele é o meio. Eis porque desde sua criação o Estado mantém incólume a característica de ente formal, contratual, e, em consequiência deta, não poder ser um fim em si mesmo. Se " a finalidade de toda associação política é a conservação dos direitos naturais e imprescritíveis do homem" não resta dúvida que, além de todo direito considerado "natural e imprescritível" se revestir de interesse público, o Estado existe somente para conservá-lo.

70 SANTOS, Boaventura de Sousa. Para uma reinvenção solidária e participativa do Estado. In: PEREIRA, Luiz Carlos Bresser; WILHEIM, Jorge, SOLA, Lourdes. (Org.) Sociedade e Estado em transformação. São Paulo: Editora UNESP: Brasília; ENAP, 1999, p. 268.

71 BOBBIO, Norberto. Estado, governo e sociedade: para uma teoria geral da política. $7^{2}$ ed. Rio de Janeiro: Paz e Terra, 1999. p. 15.

72 GALDINO, Flávio. O custo dos direitos. In: TORRES, Ricardo Lobo (Org.) Legitimação dos Direitos Humanos. Rio de Janeiro: Renovar, 2002. p. 160-1: NOGUEIRA, Alberto. Direitos do homem, direitos fundamentais e liberdades públicas: diferenciaçōes e convergências. Revista Ciências Sociais/U.G.F., Rio de Janeiro, Edição Especial, 1997, p. 148; LAFER, Celso. A soberania $e$ os direitos humanos. Lua Nova, São Paulo, n 35, 1995. p. 147.

73 BOBBIO, Norberto. A era dos direitos. Rio de Janeiro: Campus, 1996, p. 69: MORAIS, José Luis Bolzan de. Do Direito social aos interesses transindividuais: o Estado e o Direito na ordem contemporânea. Porto Alegre: Livraria do Advogado, 1996, p. 137-49; LISBOA, Roberto Senise. Contratos difusos e coletivos: consumidor, meio ambiente, trabalho, agrário, locaçāo. $2^{\mathbf{A}}$ ed. São Paulo: Editora Revista dos Tribunais, 2000, p. 62-4; SOUZA, Motauri Ciocchetti de. Ação Civil Pública e Inquérito Civil. São Paulo: Saraiva, 2001, p. 4-12; LEMOS FILHO, Flávio Pimentel de. Direito Potestativo. Rio de Janeiro: Lumen Juris, 1999, 12-8: ZAVASCKI, Teori Albino. Defesa de direitos coletivos e defesa coletiva de direitos. Revista Forense, Rio de Janeiro, vol. 329, 1995, 147-50; MANCUSO, Rodolfo de Camargo. Interesses difusos: conceitos e legitimação para agir. $5^{\circ}$ ed. São Paulo: Revista dos Tribunais, 2000, p. 80-100. 
Do provável caráter público construído a partir de "critérios de conveniência e oportunidade ${ }^{" 74}$ determinados pelo corpo social para garantir os interesses próprios de sua estabilidade, sendo certo que tais critérios tomam por base o contexto civil, onde, em princípio, os direitos são criados, resulta que o público nasce privado e por decisão política se torna estatal, ou melhor, o caráter público é exigência da própria sociedade para tornar efetiva a proteção dos valores que consagra, proteção esta que, como ente formal que é, o Estado tem por função garantir.

Segundo o Plano Diretor da Reforma do Estado os serviços não-exclusivos são serviços que "envolvem direitos humanos fundamentais, como os da educação e da saúde", daí a presença do Estado, ainda que não exclusivamente, porque direitos fundamentais são aqueles "garantidos pelos ordenamentos jurídico-positivos estatais"75, portanto correspondem a interesses públicos e reclamam função estatal.

CELSO ANTÔNIO BANDEIRA DE MELLO esclarece que existe função administrativa "quando alguém está investido do dever de satisfazer dadas finalidades em prol do interesse de outrem, necessitando, para tanto, manejar os poderes requeridos para suprí-las. ... Sem eles, o sujeito investido na função não teria como desincumbir-se do dever posto a seu cargo. Quem exerce 'função administrativa' está adstrito a satisfazer interesses públicos, ou seja, interesses de outrem: a coletividade." 76 Logo, o interesse público vincula, obriga.

Conquanto BRESSER PEREIRA nomeie as atividades plenas de interesse público como não-exclusivas de Estado, na verdade elas são não-exclusivas da sociedade $^{77}$, uma vez que o Estado foi criado para, por dever de ofício, tomá-las como sua responsabilidade ${ }^{78}$. Por um lado, tal vínculo visa superar as instabilidades próprias da natureza humana que podem vulnerar o interesse público ao deixá-lo à mercê daquilo que IMMANUEL KANT chamou de "a insociável sociabilidade"79, resultado de um "antagonismo natural"80. Por outro, busca garantir a prestação do serviço.

74 CAVALIERI FILHO, Sérgio. Programa de Responsabilidade Civil. 2* ed. São Paulo: Malheiros, 2000. p. 25-6.

75 NOGUEIRA, Alberto. Direitos do homem, direitos fundamentais e liberdades públicas: diferenciações e convergências. Revista Ciências Sociais/U.G.F., Rio de Janeiro, Ediçāo Especial, 1997. p. 131 .

76 MELLO, Celso Antônio Bandeira de. Elementos de Direito Administrativo. $3^{\mathbf{a}}$ ed. São Paulo: Malheiros, 1992. p. 21-2.

77 SANTOS, Boaventura de Sousa. Para uma reinvenção solidária e participativa do Estado. In: PEREIRA, Luiz Carlos Bresser; WILHEIM, Jorge; SOLA, Lourdes. (Org.) Sociedade e Estado em transformaçāo. São Paulo: Editora UNESP; Brasília: ENAP, 1999, p. 268.

78 MOREIRA NETO, Diogo de Figueiredo. Legitimidade e discricionariedade: novas reflexões sobre os limites e controle da discricionariedade. $1^{2}$ ed. Rio de Janeiro: Forense, 1989. p. 6-7.

79 HÖFFE, Otfried. Justiça política: fundamentação de uma filosofia crítica do direito e do Estado. São Paulo: Martins Fontes, 2001, p. 245; BOBBIO, Norberto. O futuro da democracia: uma defesa das regras do jogo. 5' ed. Rio de Janeiro: Paz e Terra, 1992, p. 22-3.

80 BOBBIO, Norberto. Liberalismo e democracia. São Paulo: Brasiliense, 2000, p. 28-9. 
Por conseguinte, o movimento de funções do Estado para a sociedade quer sempre significar que esta entende não ser mais conveniente e oportuno, ou seja, político, manter tais funções atreladas à esfera estatal, ou melhor, não há mais interesse público envolvido. Caso não seja este o significado, o serviço público estará correndo risco de não se realizar, uma vez que, por carência da "função administrativa", seu executor não estará obrigado a prestá-lo. Não é por outro motivo que a construção de espaços públicos não-estatais concebidos para além de eventualiade do altruísmo humano, assim como a formação de mercados livres, se apóia necessariamente na diligência do Estado, sendo aquelas as causas pelas quais reformas e revoluções marcam o desenvolvimento deste.

Consoante argumentos diversos apesar de relacionados, BOAVENTURA DE SOUSA SANTOS critica a concepção de serviços não-exclusivos, cujo objetivo expresso por BRESSER PEREIRA é o de substituir o Estado pelo "setor público não-estatal" naquelas funções. Alega o sociólogo que por "detrás desta distinção está a idéia de que, sempre que o Estado não demonstre ter uma vantagem comparativa, deve ser substituído no exercício das funções não-exclusivas por instituições privadas ... a análise da gênese do Estado moderno revela que nenhuma das funçōes do Estado foi originariamente exclusiva dele; a exclusividade do exercício de funçōes foi sempre o resultado de uma luta política." E arremata: "não havendo funções essencialmente exclusivas, não há, por implicação, funções essencialmente não-exclusivas". ${ }^{81}$

Com efeito, serviços públicos não-exclusivos só deveria existir na medida em que a não exclusividade tenha caráter suplementar, não sendo admitida a substituição ou a complementação porque se o interesse for público há vinculação do Estado pela totalidade de sua execução.

Conforme o exposto até o momento, da convivência entre a necessidade de manutenção dos direitos conquistados e a "insociável sociabilidade humana" resultou o desenvolvimento do Estado no sentido da formação de uma personalidade jurídica capaz de assumir obrigações e exigir direitos: as primeiras relacionadas pela doutrina aos interesses primários do Estado ${ }^{82}$, grosso modo os ditos serviços não exclusivos, e os segundos aos interesses secundários, na generalidade qualificadas como atividades exclusivas no Plano Diretor. Desta forma, o Estado brasileiro estaria sendo substituído nas obrigações, razão de ser de sua existência, o que representa, sem embargo. grande perigo para o Estado Democrático de Direito. Este perigo reside no sobredito propósito de submissão do direito à economia, sendo oportuno trazer à colação o filosófico asserto de JOSÉ JOAQUIM GOMES CANOTILHO:

81 SANTOS, Boaventura de Sousa. Para uma reinvenção solidária e participativa do Estado. In: PEREIRA, Luiz Carlos Bresser; WILHEIM, Jorge; SOLA, Lourdes. (Org.) Sociedade e Estado em transformaçāo. São Paulo: Editora UNESP; Brasília: ENAP, 1999. p. 268.

82 MELLO. Celso Antônio Bandeira de. Elementos de Direito Administrativo. $3^{\mathrm{a}}$ ed. São Paulo: Malheiros, 1992. p. 22-3; SOUZA, Motauri Ciocchetti de. Ação Civil Pública e Inquérito Civil. São Paulo: Saraiva, 2001, p. 2-4. 
“... o Estado de direito só será social se não deixar de ter como objectivo a realização de uma democracia económica, social e cultural e só será democrático se mantiver firme o princípio da subordinação do poder económico ao poder político. As tentativas de expurgação do social com o intuito de destilar um estado de direito quimicamente puro, isto é, um Estado sem o compromisso da socialidade, mais não são do que coberturas ideológicas para políticas econômicas e sociais onde não cabem deveres de solidariedade e de inclusão do outro." (sic $)^{83}$

No tocante ao perigo jurídico-administrativo, o destaque registrado é de MARIA SYLVIA ZANELLA DI PIETRO:

" $O$ aspecto principal que se quer realçar é o concernente aos riscos para os direitos sociais do cidadão, decorrentes da transferência de serviços públicos sociais para entidades privadas, acompanhada da transferência da res publica, para ser administrada sob regime jurídico próprio da empresa privada. $O$ sucesso dessa forma de parceria dependerá em grande parte da eficiência do controle. Se este não for estruturado de forma adequada, os direitos do cidadão e a proteção da res publica poderão ficar seriamente comprometidos. ${ }^{84}$

A cautela de DI PIETRO encontra eco na constatação de DONALD F. KETTL:

"Já é muito difícil aferir o desempenho das organizações estatais, mas a dificuldade aumenta quando parte substancial da atividade governamental está fora do controle direto dos administradores públicos. ... Quanto mais o governo estabelece parcerias público-privadas para cumprir suas funções, masi difícil fica sua tarefa" 85

Convém retornar aos ensinamentos de CARNELUTTI para fixar a idéia de que "na verdade o Estado é uma universitas, o que quer dizer a versio in unum, a redução à unidade dos homens que o integram" 86 . Esta redução se dá na Constituição, cuja perspectiva já se apresentava na formação do Estado moderno uma vez que "toda sociedade, na qual a garantia dos direitos não é assegurada nem a separação dos poderes determinada, não tem constituição" ${ }^{87}$.

83 CANOTILHO, José Joaquim Gomes. Estado de Direito. Cadernos Democráticos. $1^{2}$ ed. Lisboa: Gradiva, 1999. p. 39.

84 DI PIETRO, Maria Sylvia Zanella. A defesa do cidadão e da res publica. Revista do Serviço Público, Brasília: ENAP, Ano 49, n², 1998, p. 130.

85 KETTL, Donald F.. A revolução global: reforma da administração do setor público. In: PEREIRA, Luiz Carlos Bresser; SPINK. Peter Kevin. (Org.) Reforma do Estado e administração pública gerencial. Rio de Janeiro: Editora FGV, 2001. p. 115.

86 CARNELUTTI, Fracesco. Como nasce o direito. Belo Horizonte: Líder Cultural Jurídica, 2001. p. 55 .

87 COMPARATO, Fábio Konder. A afirmação histórica dos direitos humanos. $2^{\mathbf{a}}$ ed. São Paulo: Saraiva, 2001, p. 153: reprodução do texto da Declaração de Direitos do Homem e do Cidadão, França, 1789. 
Não foi por outro motivo que sabiamente o legislador constituinte originário estabeleceu no Título III -- DA ORGANIZAÇÃO DO ESTADO, no art. 23 da Constituição Federal de 1998, que as competências executivas relacionadas aos interesses primários do Estado, cujo conteúdo se refere aos nomeados serviços não-exclusivos, são competência comum dos entes federados, ou seja, todos são simultânea e comissivamente responsáveis pelo que foi lá preceituado, devendo haver, consoante o parágrafo único daquele artigo "cooperação entre a União e os Estados, o Distrito Federal e os Municípios, tendo em vista o equilíbrio do desenvolvimento e do bem-estar em âmbito nacional". No Título VIII - DA ORDEM SOCIAL, a sociedade é chamada a participar na suplementação daquelas competências, inclusive porque com ensina CAIO TÁCITO:

“Ninguém será obrigado a fazer ou deixar de fazer alguma coisa senão em virtude de lei", proclama o inciso I do artigo $5^{\circ}$, a par da regra fundamental da igualdade de todos perante a lei. Deriva desse princípio a regra de que a competência administrativa vincula-se necessariamente a uma autorização legal. Lembramos, em trabalho anterior, que "não há, em direito administrativo, competência geral ou universal. Não é competente quem quer, mas quem pode, segundo a norma de direito." 88

Por conseguinte, a Reforma em curso parece vulnerar o Estado de Democrático de Direito com graves prejuízos à tão debilitada condição social do Brasil, aumentando o fosso existente entre pobres e ricos, em franco contraste com os princípios e fundamentos da Constituição Cidadã.

\section{Conclusão}

As organizações sociais foram desenhadas como uma das instituições-chaves da Reforma do Estado. Na qualidade de entidades de serviços públicos intitulados não-exclusivos de Estado pelos reformistas, deveriam existir para suplementar aqueles serviços que o Poder Público tem obrigação de prestar, não como forma de substituição da atividade estatal ou como complementação de orçamentos. Consoante estes dois últimos objetivos, a existência das organizações sociais pode atender ao princípio da eficiência sob o ponto de vista econômico, mas certamente afronta diversos princípios jurídicos eleitos pela sociedade brsileira como norteadores do seu desenvolvimento social ao colocar em risco a res pública, e risco é opção operacional de mercado.

88 TÁCITO, Caio. Constituiçōes Brasileiras: 1988. Brasília: Senado Federal e Ministério da Ciência e Tecnologia, Centro de Estudos Estratégicos, 1999, (Coleção Constituições Brasileiras, v. 7). p. 13. 
No conjunto da Reforma Administrativa, a Lei nú 9.637/98, ainda que não venha a ser declarada inconstitucional, se mostrou ilegítima, quer porque o poder discricionário nela insito dá propositadamente margens à fraude à lei, quer porque, ao invés da discricionariedade, é o arbítrio do administrador público que ela estimula, convindo consignar o fato referente à falta de clareza originária do próprio Plano Diretor, que acabou por tornar pífia a concretização das organizações sociais, além de inviabilizar aquela reforma no seu aspecto social.

\section{Bibliografia}

ANDREWS, Christina W.; KOUZMIN, Alexander. O discurso da nova administração pública. Lua Nova, São Paulo, no 45, p. 97-129, 1998.

ARISTÓTELES. Política. São Paulo. Martin Claret, 2001. (Coleção A Obra-Prima de Cada Autor, 61).

BACELLAR, Romeu Felipe. A administração pública - tendências atuais (Reforma Administrativa). Palestra proferida em 23.10.97, por ocasião do XIX Congresso dos Tribunais de Contas do Brasil, realizado no Rio de Janeiro. Disponível em "http://www.tce.rj.gov.br/revista/artigos/r38c001.htm". Acesso em 29 out. 2001.

BOBBIO, Norberto. A era dos direitos. Rio de Janeiro: Campus, 1996.

BOBBIO, Norberto. Estado, governo e sociedade: para uma teoria geral da política. $7^{\mathrm{a}}$ ed. Rio de Janeiro: Paz e Terra, 1999.

BOBBIO, Norberto. Liberalismo e democracia. São Paulo: Brasiliense, 2000.

BOBBIO, Norberto. O futuro da democracia: uma defesa das regras do jogo. $5^{\mathrm{a}} \mathrm{ed}$. Rio de Janeiro: Paz e Terra, 1992.

BOBBIO, Norberto; MATTEUCCI, Nicola; PASQUINO, Gianfranco. Dicionário de Política. $5^{\mathrm{a}}$ ed. Brasília: Unb, 2000.

BORGES, André. Democracia vs. Eficiência: a teoria da escolha pública. Lua Nova, São Paulo. no 53, p. 159-79, 2001.

BRASIL. Ministério do Planejamento, Orçamento e Gestão. Plano Diretor da Reforma do Estado. Disponível em: "http://www.planejamento.gov.br/gestao/coneudo/publicacoes/plano_diretor/portugues_tudo.htm". Acesso em: 01.08.2002.

CANOTILHO, José Joaquim Gomes. Estado de Direito. Cadernos Democráticos. $1^{\text {a }}$ ed. Lisboa: Gradiva, 1999.

CARNELUTTI, Francesco. Como nasce o direito. Belo Horizonte. Líder Cultural Jurídica, 2001.

CASTRO, Sonia Rabello de. Habilitação: direito e governança. Revista de Administração Pública, Rio de Janeiro: FGV, vol. 35 (4), p. 111-26, jul/ago, 2001.

CAVALIERI FILHO, Sérgio. Programa de Responsabilidade Civil. $2^{\mathrm{a}}$ ed. São Paulo: Malheiros, 2000.

CHÂTELET, François, DUHAMEL, Olivier, PISIER-KOUCHNER, Évelyne. História das idéias políticas. Rio de Janeiro: Jorge Zahar, 1994. 
COMPARATO, Fábio Konder. A afirmação histórica dos direitos humanos. $2^{\mathrm{a}} \mathrm{ed}$. São Paulo: Saraiva, 2001.

DI PIETRO, Maria Sylvia Zanella. A defesa do cidadão e da res publica. Revista do Serviço Público, Brasília: ENAP, Ano 49, n² 2, p. 125-30, 1998.

DIAS, Francisco Mauro. Estado de direito, direitos humanos (direitos fundamentais), segurança jurídica e Reforma do Estado. Revista Ciências Sociais/U.G.F., Rio de Janeiro, Edição Especial, p. 253-75, 1997.

DINIZ, Maria Helena. Conflito de normas. $3^{\mathrm{a}}$ ed. São Paulo: Saraiva, 1998.

FERRAZ, Luciano. O Estado Gerencial e a Lei de Licitações Públicas. Interesse Público, Sapucaia do Sul, nº 3, p. 37-46, 1999.

FERREIRA FILHO, Manoel Gonçalves. Constituição e governabilidade: ensaio sobre a (in)governabilidade brasileira. São Paulo: Saraiva, 1995.

GALDINO, Flávio. $O$ custo dos direitos. In: TORRES, Ricardo Lobo (Org.) Legitimação dos Direitos Humanos. Rio de Janeiro: Renovar, 2002. p. 139-222.

HÖFFE, Otfried. Justiça política: fundamentação de uma filosofia crítica do direito $e$ do Estado. São Paulo: Martins Fontes, 2001.

JAEGER, Werner Wilhelm. Paidéia: a formação do hoinem grego. $3^{a}$ ed. São Paulo: Martins Fontes, 1995.

KETTL, Donald F.. A revolução global: reforma da administração do setor público. In: PEREIRA, Luiz Carlos Bresser; SPINK, Peter Kevin. (Org.) Reforma do Estado e administração pública gerencial. Rio de Janeiro: Editora FGV, 2001. p. $75-121$.

LAFER, Celso. A soberania e os direitos humanos. Lua Nova, São Paulo, $\mathrm{n}^{\circ} 35, \mathrm{p}$. 137-48, 1995.

LEMOS FILHO, Flávio Pimentel de Direito Potestativo. Rio de Janeiro: Lumen Juris, 1999.

LISBOA, Roberto Senise. Contratos difusos e coletivos: consumidor, meio ambiente, trabalho, agrário, locação. $2^{\mathrm{a}}$ ed. São Paulo. Editora Revista dos Tribunais, 2000.

MANCUSO, Rodolfo de Camargo. Interesses difusos: conceito e legitimação para agir $5^{a}$ ed. São Paulo: Revista dos Tribunais, 2000.

MEDAUAR, Odete, Direito Administrativo Moderno. $6^{\mathrm{a}}$ ed. São Paulo: Revista dos Tribunais, 2002.

MEIRELLES, Hely Lopes. Direito administrativo Brasileiro. $22^{\mathbf{a}}$ ed. São Paulo: Malheiros, 1997.

MELLO, Celso Antônio Bandeira de. Elementos de Direito Administrativo. $3^{\text {a }}$ ed. São Paulo. Malheiros, 1992.

MODESTO, Paulo. Notas para um debate sobre o princípio constitucional da eficiência. Interesse Público, Sapucaia do Sul, $\mathrm{n}^{\circ}$ 7, 2000.

MODESTO, Paulo. Reforma administrativa e marco legal das organizações sociais no Brasil - as dúvidas dos juristas sobre o modelo das organizações sociais. Revistas Diálogo Jurídico, Salvador, CAJ - Centro de Atualização Jurídica, v. I, n 9, dezembro, 2001. Disponível em "http://www.direitopublico.com.br". Acesso em: 01.08.2002. 
MORAIS, José Luis Bolzan de. Do Direito social aos interesses transindividuais: o Estado e o Direito na ordem contemporânea. Porto Alegre: Livraria do Advogado, 1996.

MORALES, Carlos Antonio. Nem privado nem estatal: em busca de uma nova estratégia para a provisão de serviços públicos. Revista do Serviço Público, Brasilia: ENAP, Ano 49, no 4, p. 115-45, 1998.

MOREIRA NETO, Diogo de Figueiredo. Legitimidade e discricionariedade: novas reflexões sobre os limites e controle da discricionariedade. $1^{\text {A }}$ ed. Rio de Janeiro: Forense, 1989.

MOREIRA NETO, Diogo de Figueiredo. Mutações do Direito Administrativo. $2^{\text {a }}$ ed. Rio de Janeiro: Renovar, 2001.

NOGUEIRA, Alberto. Direitos do homem, direitos fundamentais e liberdades públicas: diferenciaçōes e convergências. Revista Ciências Sociais/U.G.F., Rio de Janeiro, Edição Especial, p. 131-55, 1997.

ONU. Programa das Nações Unidas para o Desenvolvimento (PNUD). Relatório de Desenvolvimento Humano 2002. Disponível em: “http://www.undp.org.br/HDR/ HDR2002/default.asp". Acesso em: 31.07.2002.

PAES, José Eduardo Sabo. Fundações e entidades de interesse social: aspectos jurídicos, administrativos, contábeis e tributários. Brasília: Brasília Jurídica, 2001.

PEREIRA, Luiz Carlos Bresser. A reforma do aparelho do Estado e a Constituição brasileira. Brasília: ENAP, 1995. (Texto para discussão, $\mathrm{n}^{\circ} 1$ ).

PEREIRA, Luiz Carlos Bresser. A reforma do estado dos anos 90: lógica e mecanismos de controle. Lua Nova, São Paulo, n 45, p. 49-95, 1998.

PEREIRA, Luiz Carlos Bresser. Cidadania e res publica: a emergência dos direitos republicanos. Brasília: ENAP, 1997. (Texto para discussão, $\mathrm{n}^{\circ} 15$ ).

PEREIRA, Luiz Carlos Bresser. Da administração pública burocrática à gerencial. In:

PEREIRA, Luiz Carlos Bresser; SPINK, Peter Kevin. (Org.) Reforma do Estado e administração pública gerencial. Rio de Janeiro FGV, 2001. p. 238-70.

PEREIRA, Luiz Carlos Bresser. Exposição no Senado sobre a Reforma da Administração Pública. Brasília: MARE, 1997. (Cadernos MARE da reforma do estado; $\left.n^{\circ} 3\right)$.

PEREIRA, Luiz Carlos Bresser. Gestão do setor público: estratégia e estrutura para um novo Estado. In: PEREIRA, Luiz Carlos Bresser; SPINK, Peter Kevin. (Org.) Reforma do Estado e administração pública gerencial. Rio de Janeiro: Editora FGV, 2001. p. 21-38.

PEREIRA, Luiz Carlos Bresser. Reforma do Estado para a Cidadania. São Paulo: Editora 34, 1998.

PEREIRA, Luiz Carlos Bresser. Uma reforma gerencial da Administração Pública no Brasil. Revista do Serviço Público, Brasília: ENAP, Ano 49, nº 1, p. 5-42, 1998.

PEREIRA, Regis Velasco Fichtner. A fraude à lei. Rio de Janeiro: Renovar, 1994.

PEREIRA JR., Jessé Torres. Da reforma administrativa constitucional. Rio de Janeiro Renovar, 1999. 
SANTOS, Boaventura de Sousa. Para uma reinvenção solidária e participativa do Estado. In: PEREIRA, Luiz Carlos Bresser; WILHEIM, Jorge, SOLA, Lourdes. (Org.) Sociedade e Estado em transformação. São Paulo: Editora UNESP; Brasília: ENAP, 1999, p. 243-271.

SOUZA, Motauri Ciocchetti de. Ação Civil Pública e Inquérito Civil. São Paulo: Saraiva, 2001.

TÁCITO, Caio. Constituições Brasileiras: 1988. Brasília: Senado Federal e Ministério da Ciência e Tecnologia, Centro de Estudos Estratégicos, 1999. (Coleção Constituições Brasileiras, v. 7).

ZAVASCKI, Teori Albino. Defesa de direitos coletivos e defesa coletiva de direitos. Revista Forense, Rio de Janeiro, vol. 329, 147-60, 1995. 